\title{
Selected Aspects of the Development and Impact of Cryptographic Currencies on the Stability and Functioning of Financial Systems
}

\begin{abstract}
The first cryptographic currency (Bitcoin) was created in 2009. Since then, cryptocurrencies have undergone dynamic development, and their user numbers risen apace. This article analyses and estimates the impact, development and growth of cryptographic currencies on the stability and functioning of financial systems. The paper also examines whether cryptocurrencies fulfill the basic functions of money. The first part addresses technical and legal issues of cryptographic currencies. The second performs a statistical analysis and impact assessment on public finances, banking sector as well as individual users have been performed. Bitcoin quotes are compared to other traditional financial instruments including rate of return, coefficient of variation, range, and Pearson's correlation coefficient. The analyses which have been conducted lead to the conclusion that cryptocurrencies cannot be treated equally with money (they are treated more as investment assets), they are far more volatile than traditional financial instruments, and there is a significant similarity between cryptographic currencies and pyramid schemes.
\end{abstract}

Michał Boda, Cracow University of Economics, Faculty of Finance and Law, Department of Banking, Rakowicka 27, 31-510 Kraków, e-mail: bodam@uek.krakow.pl

Radosław Ciukaj, Cracow University of Economics, Faculty of Finance and Law, Department of Banking, Rakowicka 27, 31-510 Kraków, e-mail: ciukajr@uek.krakow.pl 
Keywords: cryptographic currencies, Bitcoin, stability, financial system.

JEL Classification: G14, G20, O33.

\section{Introduction}

With the advancement of the computerisation, as can be seen in recent decades, more and more aspects of everyday life are being transferred to the realm of virtual reality. As a result, numerous unknown phenomena have emerged, including economic ones. Cryptocurrencies are among the latest products of human ingenuity of recent years, and function solely in the virtual realm. They are intended to be instruments that are not subject to any administrative regulation, are independent of central banks, and are valued only by the market (Dopierała \& Borodo 2014, s. 1).

Given that one of the main functions of cryptocurrencies is to enable payments, national and international administrators must determine whether cryptocurrencies can be treated as money at all. The answer to this question is not an easy one, given the functions of money in the economy. These include (Podstawka 2013, p. 44):

a) as a medium of exchange - money effectively eliminates the double coincidence of wants problem by serving as a medium of exchange that is accepted in all transactions, by all parties, regardless of whether they desire each others' goods and services,

b) as a unit of account - money is a common standard for measuring the relative worth of goods and services,

c) as a store of value - money's value can be retained over the time, so it is a convenient way to store wealth.

In November 2008, a conspectus (sometimes called a manifest) was posted by a person or group of people working under the name of Satoshi Nakamoto, who expressed the need to create a new currency, based entirely on a peer-to-peer system (P2P). P2P is a communication model in a computer network that provides all participating devices with the same data sharing as the client - server architecture. This currency would allow online payments to be made directly between users, bypassing institutions or financial intermediaries. What is more, the payment system, connected by virtual currency, would be based on cryptography rather than on trust in a third parties (www.bitcoin.org/bitcoin. pdf, accessed: 14.08.2017). This is how Bitcoin (BTC), now considered the first and most common cryptocurrency, was created. Nakamoto also raised a heated discussion about contemporary forms of money. 


\section{Research Methodology}

Today, there exists a large-scale discussion about the legitimacy of the cryptocurrencies (particular Bitcoin) as a means of payment or as an investment instrument. The payment function best reflects the idea that formed the foundation for the cryptocurrencies. However, literature studies and analysis of statistical data clearly indicate that the investment function is the main premise for acquiring cryptocurrencies. The purpose of this article is to present the relationship between cryptocurrencies and other currencies and to show the impact of cryptocurrencies on public finances, the banking sector and individual users. It will also discuss the dark side of cryptocurrencies and their similarity to financial pyramid schemes. It outlines the prospects for development in the context of their payment functions. The article starts with the theoretical aspects of cryptocurrencies, including the technical and legal conditions of their functioning. Rate of return, coefficient of variation, range and Pearson correlation coefficient have been used to analyse Bitcoin quotes in relation to selected national currencies, commodities and stock indexes.

\section{Cryptographic Currencies and Forms of Modern Money}

The name "money" comes from Latin (pecunia) and means horn cattle, which in Roman times was used as a means of exchange. This suggests that anything can be established as money, relying solely on the principles of social contract. Regardless of its external form and economic system, money is defined today as a legally defined, commonly accepted means of payment that can express, store and accept values, and whose value is closely linked to real Gross Domestic Product (GDP) (Schaal 1996, p. 26).

Money can be classified according to different criteria. While the forms of money have included primitive, metallic, banking and electronic (Piaszczyński 2004, p. 19), contemporary money exists in two main forms:

a) cash - banknotes and coins,

b) deposit money - the subject of accounting records of banks and has no physical form.

New types of payment instruments have emerged which could easily replace the current forms of money. From this perspective, cryptocurrencies can be seen as an alternative to both cash and deposit money. However, any good that would fulfill the role of money must meet the following criteria, e.g. (Bala, Kopyściański \& Srokosz 2016, p. 57): 
a) durability - it needs to last,

b) portable - is easy to carry, convenient and easy to use,

c) divisible - it can be broken down into smaller denominations,

d) hard to counterfeit - it can not easily be faked or copied,

e) must be generally accepted by a population,

f) valuable - generally holds value over time.

By analysing the technological aspects of the creation and operation of cryptocurrencies, it can be concluded that they fulfill all of the above-mentioned characteristics satisfactorily, and some features are even fulfilled to a greater extent than money in cash or deposit money form. Thus, cryptocurrencies could be accepted as modern forms of cash.

\section{Technical Conditions for the Functioning of Cryptographic Currencies - Bitcoin}

The Bitcoin payment network is built on the basis of a cryptographic $\mathrm{P} 2 \mathrm{P}$ protocol that gives all users equal rights. In other words, users around the world - or, more precisely, their computers - create and control the network they belong to. This means there is no central server responsible for Bitcoin. From the point of view of a regular user, Bitcoin is just a programme installed on a computer or mobile phone, one that allows access to a virtual wallet that sends and receives bitcoins (www.bitcoin. org/bitcoin.pdf, accessed: 15.08.2017).

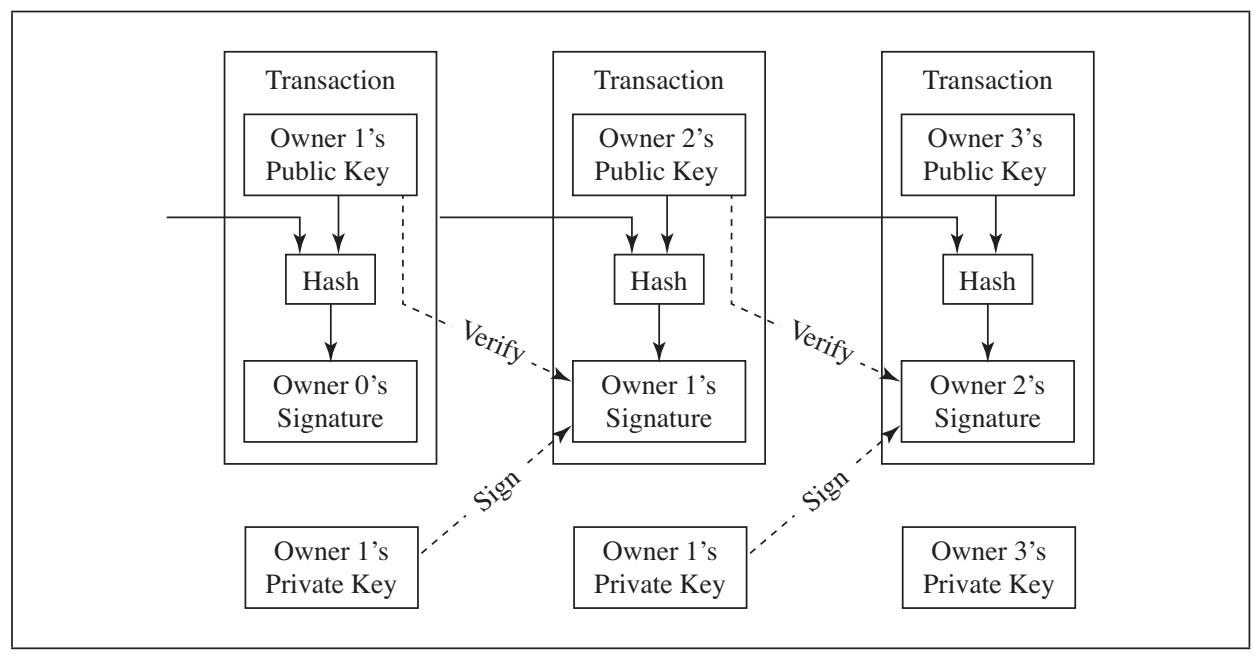

Fig. 1. The Bitcoin Network Transaction Diagramme

Source: (Nakamoto 2017). 
The BTC wallet consists of three numbers:

a) a private key - used to "sign" (authorise) a transaction,

b) a public key - generated from a private key and serves as an address,

c) an address - consists of 27 to 34 alphanumeric characters and can be compared to an email address. If a wallet user wants to pay or transfer bitcoins, he or she must provide the wallet address where the corresponding balance is stored.

The Bitcoin network is based on a widely available, scattered database. This is a chronological list of the Bitcoin network and is based on a widely available, scattered database. This is a chronological list of all transactions, otherwise called block chains. Figure 1 illustrates the Bitcoin network transaction diagramme.

A transaction is a message of some value between the addresses. It is executed and authorised using a private key by each user. All current transactions, before approval, are collected and saved in the block every 10 minutes. In order to prevent the double release of bitcoins or forgery, coherence and chronological chains of blocks are based on "Proof of Work" (PoW), or evidence of action taken. This involves calculating, with a certain probability of the hash (a string of letters and numbers used as a shortcut) containing information about current transactions and the hash of the previous block. This task is performed by "miners". In short, every transaction made between users is confirmed by the P2P network in an expanding process. This process is a kind of competition, because new bitcoins are randomly allocated to users who provide computing power. The greater the computational power a user gives, the greater the probability he or she will receive new bitcoins. Coin allocation follows the condition of "block break", which means solving a cryptographic puzzle (Dopierała \& Borodo 2014, p. 3).

\section{Legal Aspects of Cryptocurrencies - the Example of Bitcoin}

Along with increasing interest in cryptocurrencies among societies throughout the world, legal aspects of the virtual currency have become one of the most important issues. The attitude of authorities to cryptographic currencies in different countries remains unclear. Officially, cryptocurrencies, including Bitcoin, do not - and likely will not for the foreseeable future - have legal or financial definitions. Despite this, some authorities have issued statements defining their status in the light of existing legislation.

In Poland, the Ministry of Finance has used the following legal acts to define Bitcoin:

a) The Act of 27 July 2002 Foreign Exchange Law (Ustawa Prawo dewizowe), Journal of Laws of 2002 no 141 item 1178, 
b) The Act of 12 September 2002 on Electronic Payment Instruments (Ustawa o elektronicznych instrumentach płatniczych), Journal of Laws of 2002 no 169 item 1385 ,

c) The Act of 19 August 2011 on Payment Services (Ustawa o ustugach płatniczych), Journal of Laws of 2011 no 199 item 1175, as amended,

d) The Act of 29 July 2005 on Trading in Financial Instruments (Ustawa o obrocie instrumentami finansowymi), Journal of Laws of 2010 no 211 item 1384, as amended.

The Ministry of Finance has declared that operating and trading with cryptocurrencies is not illegal. However, given the lack of universal acceptability, they cannot be considered domestic or foreign currency, nor as a means of payment. Cryptocurrencies may also not be covered by the definition of electronic money or financial instruments, Further, cryptocurrency transactions are not payment transactions, because they only cover payment or cash transfer (Kurek 2015, p. 153).

The European Central Bank issued a detailed report on digital currency in 2012 (https://www.ecb.europa.eu/pub/pdf/other/virtualcurrencyschemes201210en.pdf, accessed: 17.08.2017), showing the differences between typical electronic currency and virtual currency. According to the report, the European Union does not classify any virtual currency as electronic money because, according to Directive 2000/46/EC, money is necessarily related to the claim to the issuer to issue an appropriate amount of money, which in the case of cryptocurrencies cannot be stated, because there is no issuer. In 2013, the European Banking Authority (EBA) issued a warning about the possible risks of theft and fraud virtual currencies posed.

Some countries have a favourable attitude towards cryptographic currencies, although with some degree of distrust. The Belgian National Bank, along with other financial institutions, withdrew an official warning statement about investments in Bitcoin. In Germany, Bitcoin is not considered a currency, but is defined as "private money" and included in units of account (https://bitcoinmagazine.com/ articles/regulation-bitcoins-germany-first-comprehensive-statement-bitcoinsgerman-federal-financial-supervisory-authority-bafin-1391637959/, accessed: 17.08.2017). In the United States, each state has its own cryptocurrency regulation, though state bodies have acknowledged that Bitcoin's anonymity may lead to money laundering, terrorist financing or drug trafficking (http://www.ibtimes.com/ bitcoin-new-york-state-continues-its-path-regulating-virtual-currency-1721103, accessed: 17.08.2017). 


\section{Examples of Other Cryptographic Currencies}

Bitcoin was created in 2008 and by 2011 was the only cryptographic currency in the world. However, in the course of time, Bitcoin derivatives also started to emerge, and often are called altcoins (alternative coins). Most of these coins either have already been forgotten or have very small capitalisation, because they did not bring in any technological innovation. However, at least several cryptocurrency derivatives deserve attention, e.g.:

a) Namecoin (NMC) - the first alternative cryptocurrency, it was launched in April 2011. Mostly based on Bitcoin source code. The difference between these two cryptocurrencies is that Namecoin acts simultaneously as a decentralised DNS (Domain Name System). This is because NMC allows one to register in the chain of blocks one's own Internet domain with the .bit22 ending, so that it is not subject to ICANN supervision (The Internet Corporation for Assigned Names and Numbers supervision). In practice, this allows for domain registrations that cannot be blocked by any authority (www.wiki.namecoin.info, accessed: 18.08.2017);

b) Litecoin (LTC) - the work of Google employee Charles Lee. It was created in October 2011 and now has the second largest capitalisation (after BTC). The main difference is the change in the Proof of Work algorithm from SHA-256 to Scrypt. This difference raises the security of the network, and the special equipment designed for the expansion of Bitcoin cannot be used to expand Litecoin (www. coinmarketcap.com/, accessed: 18.08.2017);

c) Primecoin (XPM) - a very interesting currency because its supply is not precisely defined by the values in the source code. The final amount of coins is not well known, because it is based on special numbers of primitive numbers strings, which are simultaneously discovered during expansion (www.primecoin.io/bin/ primecoin-paper.pdf, accessed: 18.08.2017);

d) Darkcoin (DRK) - created in 2014, DRK is a relatively new cryptocurrency. Nowadays, in the world of cryptocurrencies, new cryptocoins are created with a view to having the most secure, anonymous system. Darkcoin has a special algorithm that is supposed to combine multiple transactions into an anonymous one in order to prevent tracing individual transaction histories.

\section{Analysis of Bitcoin Volatility Quotes in Relation to Selected National Currencies, Commodities and Stock Indexes}

The high volatility of cryptocurrencies relative to national currencies raises the question of a possible impact on the stability and functioning of financial markets. As the last section made clear, there are many cryptocurrencies on the 
market. But for this study Bitcoin (BTC) was selected as it is the most used and recognised one in the world, has the largest capitalisation and trading volumes. BTC quotes in relation to national currencies (EUR, USD, PLN, CNY, GBP) and gold have been compared with quotes of other traditional currency pairs (such as EUR/USD, EUR/PLN, etc.), quotes of selected commodities (gold, Brent oil) and stock indexes (SP 500, FTSE 250, DAX).

The following statistical methods were used: rate of return, coefficient of variation, range and Pearson correlation coefficient. Based on the data in Table 1, BTC was significantly more volatile than other currencies. For BTC, the daily rates of return were in the range of $-36.25 \%$ to $52.89 \%$, while traditional financial instruments ranged from $-8.57 \%$ to $9.10 \%$. The situation with the coefficient of variation was similar. The average value of this indicator for BTC was $28.27 \%$,

Table 1. Intraday Statistical Analysis of BTC Quotes Relative to National Currencies and Selected Commodities and Stock Market Indices in the Period 19.07.2010-15.08.2017 (in \%)

\begin{tabular}{|c|c|c|c|c|c|c|}
\hline \multirow{2}{*}{ Relation } & \multicolumn{2}{|c|}{ Rate of Return } & \multirow{2}{*}{$\begin{array}{l}\text { Coefficient } \\
\text { of Variation }{ }^{\mathrm{a}}\end{array}$} & \multirow{2}{*}{$\begin{array}{l}\text { The Highest } \\
\text { Value Shift }{ }^{\mathrm{b}}\end{array}$} & \multirow{2}{*}{$\begin{array}{l}\text { The Lowest } \\
\text { Value Shift }\end{array}$} & \multirow{2}{*}{ Range $^{\mathrm{d}}$} \\
\hline & the Highest & the Lowest & & & & \\
\hline BTC/EUR & 39.97 & -22.09 & 25.41 & 44.64 & -38.33 & 50.15 \\
\hline BTC/USD & 52.89 & -36.25 & 48.14 & 97.96 & -56.57 & 100.02 \\
\hline BTC/PLN & 39.57 & -22.48 & 25.17 & 44.22 & -38.29 & 49.97 \\
\hline BTC/CNY & 21.50 & -24.10 & 16.33 & 21.70 & -29.22 & 39.49 \\
\hline BTC/GBP & 40.19 & -22.38 & 25.55 & 44.86 & -38.73 & 50.07 \\
\hline XAU/BTC & 23.07 & -28.62 & 29.00 & 60.49 & -31.00 & 66.44 \\
\hline EUR/USD & 3.01 & -2.90 & 2.23 & 3.86 & -4.50 & 4.50 \\
\hline EUR/PLN & 2.70 & -3.03 & 2.23 & 4.39 & -3.21 & 4.73 \\
\hline EUR/CNY & 3.06 & -1.54 & 1.95 & 3.60 & -3.14 & 3.64 \\
\hline EUR/GBP & 6.78 & -2.05 & 4.75 & 9.22 & -2.28 & 9.32 \\
\hline XAU/EUR & 9.02 & -8.57 & 7.03 & 14.19 & -9.60 & 14.19 \\
\hline CB.F USD & 9.10 & -8.30 & 5.75 & 10.31 & -9.51 & 12.11 \\
\hline SP 500 & 4.67 & -6.59 & 3.81 & 5.80 & -6.61 & 6.61 \\
\hline FTSE 250 & 3.58 & -7.19 & 5.98 & 4.09 & -12.25 & 12.25 \\
\hline DAX & 6.05 & -7.07 & 4.65 & 6.78 & -8.14 & 8.94 \\
\hline
\end{tabular}

${ }^{a}$ calculated as the quotient of standard deviation and the opening price, ${ }^{b}$ calculated as the quotient of the highest price and the opening price, ${ }^{\mathrm{c}}$ calculated as the quotient of the lowest price and the opening price, ${ }^{\mathrm{d}}$ calculated as the quotient of the difference between the highest and lowest prices and the opening price.

Source: the authors' own elaboration based on: https://stooq.pl information (accessed: 15.08.2017) and (Bala, Kopyściański \& Srokosz 2016, p. 90). 


\begin{tabular}{|c|c|c|c|c|c|c|c|c|c|c|c|c|c|c|c|}
\hline$\stackrel{x}{a}$ & $\times$ & $x$ & $x$ & $\times$ & $x$ & $x$ & $x$ & $\times$ & $\times$ & $\times$ & $\times$ & $\times$ & $\times$ & $x$ & $\stackrel{8}{.}$ \\
\hline 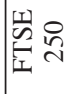 & $\times$ & $x$ & $x$ & $\times$ & $\times$ & $x$ & $x$ & $x$ & $x$ & $\times$ & $\times$ & $\times$ & $\times$ & $\stackrel{8}{8}$ & $\mathfrak{n}_{0}^{\infty}$ \\
\hline $\begin{array}{l}8 \\
\text { n } \\
\text { nे }\end{array}$ & $\times$ & $x$ & $x$ & $x$ & $x$ & $x$ & $\times$ & $\times$ & $\times$ & $\times$ & $\times$ & $\times$ & $\stackrel{8}{8}$ & ?̊? & \begin{tabular}{l} 
?ִ \\
\hdashline
\end{tabular} \\
\hline ڤึ & $x$ & $x$ & $\times$ & $\times$ & $\times$ & $\times$ & $x$ & $\times$ & $\times$ & $\times$ & $\times$ & 8 & $\tilde{c}_{0}^{0}$ & $\begin{array}{l}\stackrel{\infty}{\sim} \\
\stackrel{0}{0}\end{array}$ & तิ \\
\hline 㞸占 & $\times$ & $x$ & $x$ & $\times$ & $\times$ & $\times$ & $\times$ & $\times$ & $\times$ & $\times$ & 8 & 8 & $\frac{m}{9}$ & $\stackrel{9}{0}$ & $\stackrel{8}{0}$ \\
\hline
\end{tabular}

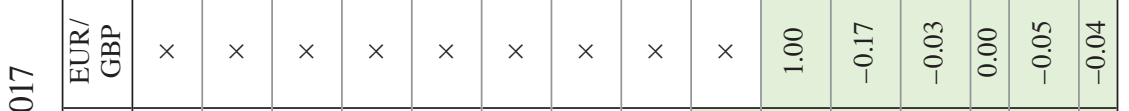

กิ

$\stackrel{\infty}{\infty}$

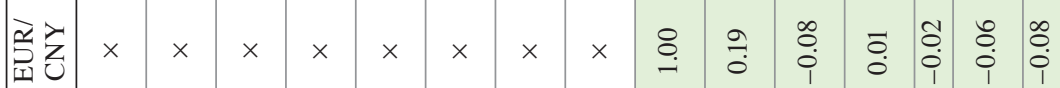

至

궁

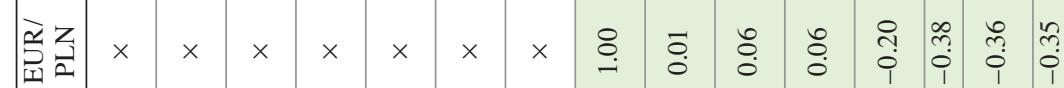

ல̊ำ

궁

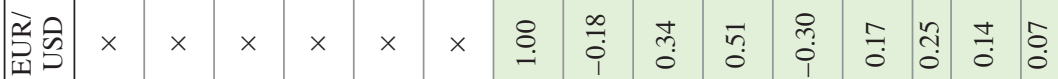

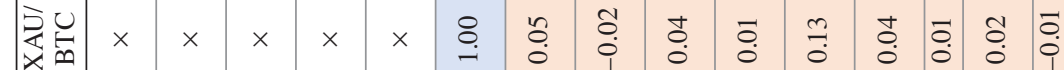

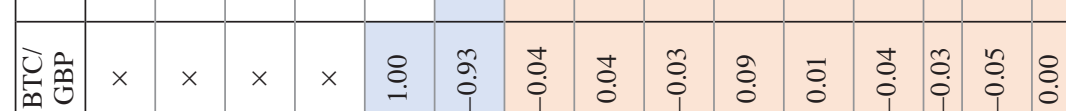

节

के

$\ddot{2}$

กิ

$\frac{2}{0}$

范 $\infty$

竞节

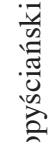

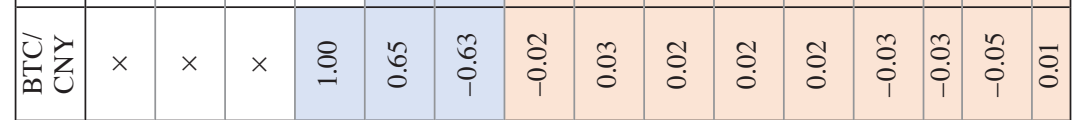

氙

吾造

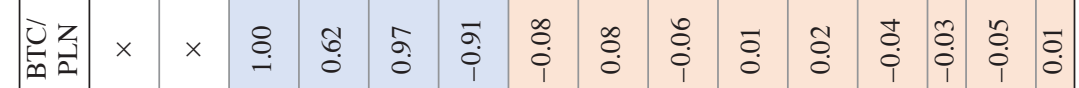

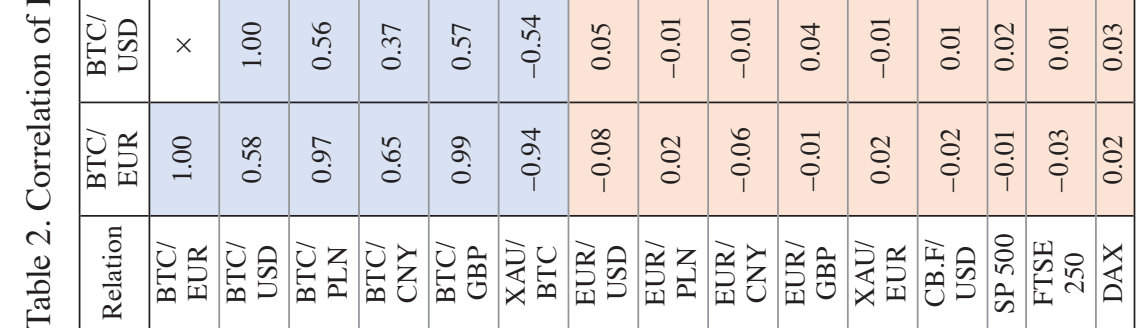

हี.

范

을

¿ 0

을

वें

च

पठ ठठ

సั

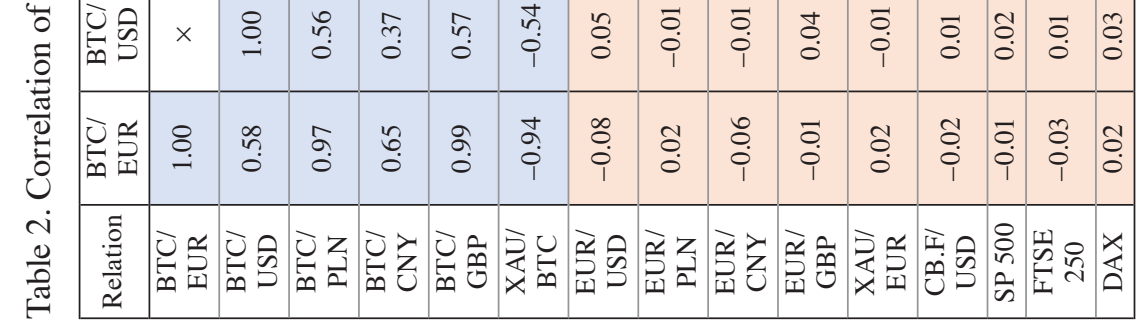
节 0 o 흥

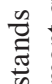
娄 $\frac{\pi}{0}$

응

ता क

营 奇

F焉 
while for traditional quotations it was $4.27 \%$, confirming BTC's higher risk as an investment. The highest daily increase and decline against the opening price occurred for the BTC/USD pair - the rates of return were $97.96 \%$ and $-56.57 \%$, respectively.

The biggest changes to quotes of traditional instruments took place with the price of gold and euro (XAU/EUR). However, the scale of changes was many times lower than that afflicting the BTC/USD pair - the highest and the lowest value shift were, respectively, $14.19 \%$ and $-9.60 \%$. The average intraday range (in relation to opening price) for BTC quotes was $59.36 \%$ while for the rest of the financial instruments in this study, it was $8.48 \%$ (Bala, Kopyściański \& Srokosz 2016, p. 89-91; Kądziołka 2016, p. 12-14, 38-42; https://coinmarketcap. com/\#EUR, accessed: 15.08.2017).

In order to assess the full impact of BTC's volatility on financial markets, a daily correlation of return rates has been made (Table 2). The correlation between the rate of BTC's return and national currencies was positive, while for XAU/BTC quotes, there was a very strong but negative correlation. In turn, the interconnectedness between pairs of traditional financial instruments was weak. Analysis of the daily rate of return on BTC and traditional financial instruments indicates a lack of correlation between tested variables. On the assumption that spurious regression does not occur, it can be concluded that the high volatility of BTC and others cryptocurrencies will not affect the rest of the financial market (Bala, Kopyściański \& Srokosz 2016, p. 90-91; Kądziołka 2016, p. 42).

BTC quotes against other financial instruments prove more volatile because, among other things, the BTC exchange rate is determined on market terms, which is neither regulated nor controlled by any supervisory authority. Hence there is no mechanism to prevent currency speculation or limit foreign-exchange risk and potential loss. The high volatility of BTC quotes is also a result of low market turnover in contradistinction to other instruments. To sum up, all of these factors limit the trust people are willing to put not only in BTC, but all cryptocurrencies, regardless of whether they were created to perform payment functions. With such a limited trust in reality, cryptocurrencies are treated not as a currency but a high-risk financial asset (Bala, Kopyściański \& Srokosz 2016, p. 89, 91; Markiewicz \& Nowak 2015, p. 91; Homa 2015, p. 134).

\section{The Development of Cryptocurrencies and Their Impact on the Economy}

The increased use and distribution of cryptographic currencies can have specific effects on the the economy, particularly in public finance, the banking system, financial markets, and even for individual users. Cryptocurrencies can 
significantly expand the grey economy, creating as they do the opportunity to establish and operate an unregistered business in which deals (e.g. for drugs and crimes) are settled by unidentified entities. They are also used to launder money. The anonymity of users, speed of execution of transactions and the ability to exchange them on stock exchanges makes it possible to introduce laundered money into an economy or to finance illegal activities. The common denominator of these threats is mainly users' anonymity, which contributes to reducing the effectiveness of fiscal control by authorised state agencies, potentially reducing public finance sector revenue. It is also unfair to those who square up to their tax liabilities.

For the banking sector, cryptocurrencies are perceived as competition and a threat to credit institutions, and as a result also to deposit money that they create in the process of multiplying deposits. Replacing national currencies created by central banks with cryptographic currencies would mean that both central banks (which would lose control of money supply) and commercial banks would no longer be needed. Banks currently have a monopoly on creating money, which may be one factor that prevents cryptocurrencies - the supply of which is limited - from developing further. For reference, there are 21 million units of Bitcoin available. While the inability to create new units reduces the risk of inflation, affecting economic stability, limited supply, can in the long term, on the other hand, promote deflation. Furthermore, as the number of services and goods increases relative to the constant quantity of cryptographic currency units, a shortage of the latter would ensue. Cryptocurrencies would therefore cease to fulfill a medium of exchange function in favour of the store of value function (further explaining why cryptocurrencies are not able to function as basic money). The idea of replacing national currencies with cryptographic currencies would undoubtedly bring economic growth to a standstill (Bala, Kopyściański \& Srokosz 2016, p. 102-105; Kądziołka 2016, p. 35-37; Markiewicz \& Nowak 2015, p. 91; Homa 2015, p. 21).

Cryptocurrencies ensure a higher level of privacy than standard electronic payments. For this reason, they have been repeatedly used to regulate transactions for illicit sales of weapons or drugs, ransom demands, and to finance terrorism (e.g. the Silk Road service closed by the FBI in October 2013). There are also the multiple controversies their numerous similarities to pyramid schemes have given rise to, foremost among them the "network effect". This phenomenon is based on the fact that economic benefits for a current group of cryptocurrency holders increase as new users get in on the action. This applies especially to the creators and users who have been invested from the beginning, and who have an advantage over the rest due to their ability to mine cryptocurrencies in the early stages at minimal cost. With time, a larger number of individuals cause the use and distribution of cryptocurrencies to rise, pushing up their market value and 
providing an opportunity to exchange them for national currencies or other real goods and services. Other similarities include the fact that new users exchange on cryptographic currency stock exchange (or currency exchanges) official and legally-accepted national currencies for virtual money which has no intrinsic value. An excellent example of a pyramid scheme is a trading platform called cryptodouble.com. The whole mechanism of this platform was based on promise of doubling deposits of each user after they have 100 hours of transactions under their belt. At the beginning, payments were made from contributions from new users. However, after some time, the stock exchange was shut down. As a result, users irretrievably lost 2233 Bitcoins, or roughly 9,400,930 USD.

In summary, a new type of pyramid scheme, one based on cryptocurrencies, has emerged. A crucial characteristic is the significant imbalance in the number of BTC holders. As Table 3 shows, $0.78 \%$ of users own and control $89.20 \%$ of the total BTC market value. This can lead a minority of BTC holders to profit thanks to their dominance in the market. Moreover, BTC's total market capitalisation is approximately 67 trillion USD, a number greater than almost $85 \%$ of the listed companies in the S\&P 500. The manic sentiment and price activity is very similar to the tulip bubble of the 17th century in the Netherlands (Bala, Kopyściański \& Srokosz 2016, p. 91-95; Szymankiewicz 2014, p. 87-90, 92-95; Kądziołka 2016, p. 37; https://www.cryptocoinsnews.com/bitcoin-ponzi-cryptodouble-disappearsleast-2233-bitcoins/; https://www.theguardian.com/technology/2013/oct/08/silkroad-hack-suspicion-fbi-server; https://www.cnbc.com/2017/07/20/bitcoin-bubbledwarfs-tulip-mania-from-400-years-ago-elliott-wave.html, accessed: 15.08.2017).

Table 3. Distribution of BTC

\begin{tabular}{|l|c|c|c|c|}
\hline \multicolumn{1}{|c|}{ Balance } & $\begin{array}{c}\text { Number } \\
\text { of Addresses }\end{array}$ & $\begin{array}{c}\text { Number } \\
\text { of Addresses } \\
\text { in Total (\%) }\end{array}$ & $\begin{array}{c}\text { Number } \\
\text { of BTC Coins }\end{array}$ & Value in USD \\
\hline $0-0.001$ & $11,317,126$ & 59.4 & 2,078 & $8,460,766$ \\
\hline $0.001-0.01$ & $3,302,678$ & 17.4 & 12,563 & $51,143,169$ \\
\hline $0.01-0.1$ & $2,588,875$ & 13.6 & 80,872 & $329,225,318$ \\
\hline $0.1-1$ & $1,211,173$ & 6.4 & 396,687 & $1,614,892,334$ \\
\hline $1-10$ & 472,576 & 2.5 & $1,291,276$ & $5,256,711,999$ \\
\hline $10-100$ & 129,798 & 0.7 & $4,340,986$ & $17,671,912,361$ \\
\hline $100-1,000$ & 16,497 & 0.1 & $3,828,754$ & $15,586,641,907$ \\
\hline $1,000-10,000$ & 1,672 & 0.0 & $3,546,960$ & $14,439,474,299$ \\
\hline $10,000-100,000$ & 118 & 0.0 & $2,898,511$ & $11,799,677,004$ \\
\hline $100,000-1,000,000$ & 1 & 0.0 & 119,080 & $484,766,441$ \\
\hline Aggregated & $19,040,514$ & 100 & $16,517,767$ & $67,242,905,598$ \\
\hline
\end{tabular}

Source: https://bitinfocharts.com/pl/top-100-richest-bitcoin-addresses.html (accessed: 21.08.2017). 


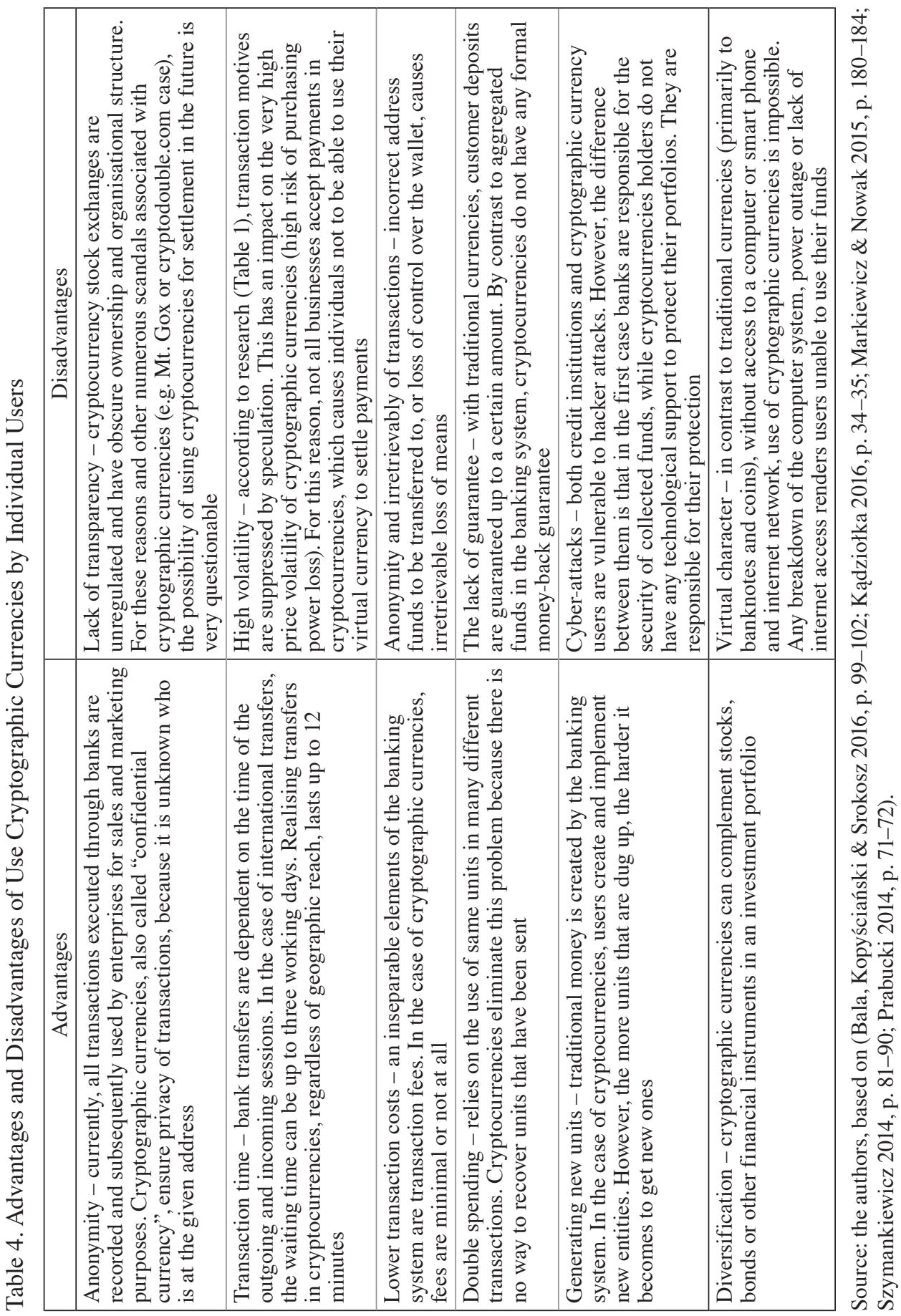


Acceptance of any object or secure verifiable record as money is an economic and legal issue. From an economic point of view, money is a unit of account, a medium of exchange, a standard of deferred payment and a store of value. Cryptocurrencies function indirectly as a unit of account. Although it is possible to compare the value of goods and services expressed in BTC or other cryptographic currencies, due to the limited possibilities for exchanging most goods and services for cryptocurrencies, determination of their value occurs only after conversion from a national currency. Because the value of cryptographic currencies is influenced by the exchange rate of national currencies (which have a specified purchasing power), and cryptocurrencies are treated as investment assets, it is impossible to directly determine prices in particular cryptographic currencies. The next function (medium of exchange) is related to use of money (as a universal equivalent) to facilitate buy-sell transactions for goods and services. However, it is important to keep in mind that intermediary instruments must be accepted by both parties to a transaction. This function is not fulfilled by cryptographic currencies, because they are not widely accepted intermediary instruments in routing. The third function of money - a standard of deferred payment, which refers to the possibility of regulating different types of liabilities (e.g. tax, loans, social contributions, salaries, etc.) - is also not achieved by cryptocurrencies.

This is so because, first, cryptographic currencies are not regulated by law, which is why it is impossible to use them to regulate tax liabilities. Second, because it is impossible to control their quantities in the economy, they are not approved by the monetary authorities to be used as money in circulation. Finally, in terms of their functioning as a store of value, the limited supply of cryptocurrencies, in accordance with theory, should cause them to appreciate in the long run, which may induce people to accumulate them. On the other hand, the intangible form of cryptographic currencies (as opposed to gold, for example), the lack of guarantee of their value and state supervision (lack of guaranteed funds, as in the case of bank deposits) all combine to reduce people's confidence in accumulating savings using cryptocurrency as the medium. To sum up, cryptocurrencies do not fulfill the functions of money. In this light, they are treated more as financial instruments (investment assets) than as money (Bala, Kopyściański \& Srokosz 2016, p. 95-98; Owsiak 2015, p. 128-129; Prabucki 2014, p. 80).

Currently, the total number of Bitcoin users is over 19 million. Benefits and threats of use cryptographic currencies by individual users are presented in Table 4. 


\section{Conclusion}

Mining (digging up) new cryptographic currency units requires high computing power and a lot of time, which drives up electricity consumption. Nevertheless, more serious issues than the technical aspects of growth in use and distribution of cryptocurrencies are related to economic aspects. Cryptographic currency quotations show that these currencies are far more volatile than traditional national currencies and other financial instruments, limiting people's trust. It should also be emphasised that the original premise of cryptocurrencies as a vehicle for transactions gave way to speculation, so investment assets are treated as a cryptographic currency.

Secondly, how cryptographic currencies are created and distributed qualifies them as a potential new type of pyramid scheme. The creators of cryptocurrencies, who produce at low cost and quickly obtain new untis, have the most to gain. When cryptographic currencies achieve a high value, units are sold for traditional currencies, which can cause quotations to collapse and spell tremendous losses for other users. Third, the anonymity of cryptocurrency users has far-reaching consequences, giving rise to money laundering, financing illegal activities (including terrorism), and harming public finances (i.e. taxes are evaded). Finally, in view of current economic theory, cryptographic currencies cannot be considered money because they do not fully achieve all of the functions of money. The unit of account function is performed indirectly, while they are entirely unable to function as a medium of exchange and standard of deferred payment, as it is debatable whether they store value. Even if cryptocurrencies fulfill these functions in the future and become fully legal tender, deflation will result in the long term.

In the longer term, further development and distribution of cryptographic currencies will depend primarily on the legal regulations and public oversight of entities that use cryptographic currencies (including the creation of a prevention mechanism in order to counteract the formation of pyramid schemes). For cryptocurrencies to completely replace current national currencies, how the economy functioned would have to change entirely.

\section{Bibliography}

Bala S., Kopyściański T., Srokosz W. (2016), Kryptowaluty jako elektroniczne instrumenty płatnicze bez emitenta. Aspekty informatyczne, ekonomiczne i prawne [Cryptocurrencies as electronic payment instruments without an issuer. IT, economic and legal aspects], Wydawnictwo Uniwersytetu Wrocławskiego, Wrocław.

Dopierała Ł., Borodo A. (2014), Znaczenie waluty kryptograficznej Bitcoin jako środka wymiany [The importance of Bitcoin's crypto currency as a means of exchange], "Współczesna Gospodarka", vol. 5, no 2. 
Homa D. (2015), Sekrety bitcoina i innych kryptowalut. Jak zmienić wirtualne pieniadze $w$ realne zyski [Secrets of bitcoin and other cryptocurrencies. How to change virtual money into real profits], Helion, Gliwice.

Kądziołka K. (2016), Inwestycje w internecie. Bitcoin i inne kryptowaluty [Investments on the Internet. Bitcoin and other cryptocurrencies], Rozpisani.pl, Łódź.

Kurek R. (2015), Bitcoin a regulacje prawno-podatkowe w Polsce i na świecie [Bitcoin and legal and tax regulations in Poland and in the world], "Prace Naukowe Uniwersytetu Ekonomicznego we Wrocławiu”, nr 397, https://doi.org/10.15611/pn.2015.397.11.

Markiewicz P., Nowak S. (2015), Bitcoin. Przyszłość inwestowania [Bitcoin. The future of investing], Wydawnictwo Naukowe PWN, Warszawa.

Nakamoto S. (2017), A Peer-to-peer Electronic Cash System, http://bitcoin.org (accessed: 15.08.2017).

Owsiak S. (2015), Finanse [Finance], PWE, Warszawa.

Piaszczyński W. (2004), Anatomia pieniądza [Anatomy of money], Script, Warszawa.

Podstawka M. (2013), Pieniadz. [Money] (in:) M. Podstawka (ed.), Finanse [Finance], Wydawnictwo Naukowe PWN, Warszawa.

Prabucki R. (2014), Problemy prawne zwiazane z używaniem monet wirtualnych $w$ Polsce $i$ na świecie [Legal problems related to the use of virtual money in Poland and in the world] (in:) M. Węgrzyn, J. Jabłoński, M. Nowakowski (eds) Transakcje i monety internetowe. Kryptologia a biznes - bezpieczeństwo stosowane [Internets' transactions and money. Cryptology and business - applied security], Wydawnictwo BTC, Legionowo.

Schaal P. (1996), Pieniadz i polityka pieniężna [Money and monetary policy], PWE, Warszawa.

Szymankiewicz M. (2014), Bitcoin. Wirtualna waluta internetu [Bitcoin. Virtual Internet currency], Helion, Gliwice.

\section{Rozwój i wpływ walut kryptograficznych na stabilność i funkcjonowanie systemu finansowego - wybrane aspekty}

(Streszczenie)

Pierwsza kryptowaluta (bitcoin) powstała w 2009 r. Od tego czasu kryptowaluty bardzo dynamicznie się rozwijają, systematycznie wzrasta też liczba ich użytkowników. Celem artykułu jest analiza i ocena rozwoju i wzrostu częstości wykorzystywania walut kryptograficznych oraz ich wpływu na stabilność i funkcjonowanie systemu finansowego. Rozważano też, czy kryptowaluty spełniają funkcje pieniądza. Poruszono kwestie techniczne oraz prawne walut kryptograficznych, dokonano analizy statystycznej - notowania bitcoina zostały porównane do notowań innych tradycyjnych instrumentów finansowych z wykorzystaniem stopy zwrotu, współczynnika zmienności, rozstępu oraz współczynnika korelacji Pearsona, oraz oceny wpływu na finanse publiczne, sektor bankowy czy indywidualnych użytkowników. Przeprowadzone analizy pozwalają sformułować wnioski, że waluty kryptograficzne nie mogą być traktowane na równi z pieniędzmi (stanowią one aktywa inwestycyjne), ich notowania wykazują bardzo dużą zmienność względem innych tradycyjnych instrumentów oraz występuje bardzo duże podobieństwo walut kryptograficznych do piramid finansowych.

Słowa kluczowe: waluty kryptograficzne, bitcoin, stabilność, system finansowy. 